\title{
AC 2007-1430: TECHNOLOGY LITERACY FOR THE TECHNOLOGICALLY LITERATE
}

\section{Richard Devon, Pennsylvania State University}

Richard Devon is Professor and Director of the Engineering Design Program at Penn State. His interests are in design education, innovative design, global design, and design ethics.

David Ollis, North Carolina State University 


\section{Technology Literacy for the Engineering Students}

\section{Introduction}

Many view technological literacy (TL) as important for people to function politically and culturally $^{1,2}$, and to work productively in modern industrial societies in which technology is so pervasive. ${ }^{2}$

The report on an NSF sponsored workshop at eth National Academy of Engineering in 2005 includes the statement that technological literacy is important because,

We live in a technological world. Living in the twenty-first century requires much more from every individual than a basic ability to read, write, and perform simple mathematics. Technology affects virtually every aspect of our lives, from enabling citizens to perform routine tasks to requiring that they be able to make responsible, informed decisions that affect individuals, our society, and the environment. Citizens of today must have a basic understanding of how technology affects their world and how they exist both within and around technology. ${ }^{3}$

While persuasive in general, there are many caveats to these propositions:

1. It is not possible to be literate about all, or even most, technologies. Doctors, electrical engineers, and chemical engineers, for example, typically live in largely mutually exclusive worlds. $^{2}$

2. It may be more important to be able to think sensibly about a technology, its costs and benefits and for whom, than to understand how it works. ${ }^{4}$

3. In a diverse world, there will be people whose talents and lives do not require "technological literacy," and whose views of technology may be valuable precisely because of that. ${ }^{4}$

4. Technology has become increasingly idiot proof for users, even while it has become increasingly complex for those who produce and maintain technology. It is also pervasive and an integral part of growing up and being educated. As such the need for programs in technological literacy is diminished

5. The use of information technology in the workplace and the need to prepare students for careers that use information technology has long been the cornerstone of policies for the use of TL in raising productivity. This seems indisputable, but the market is a much stronger driver than policy in achieving this. Where policy can help is in reducing the digital divide that leave students from low income backgrounds stranded in low income jobs. ${ }^{5}$ It is also helpful in conditions of continuous technological change to maintain currency through lifelong education.

Thus the argument for technological literacy must rest on specific cases where it is important. This includes setting specific goals for any intervention. It also needs to be shown whether policy, the market, or both will drive the intervention. This paper will show the value of using 
technology literacy in engineering education, where it might be assumed to be redundant. Indeed, many early proponents of the "Technology as the new Liberal Arts" assumed that it would involve engineers teaching non-engineers about technology. This potential burden on engineering faculty never really materialized outside of selected STS courses and texts, often outstanding. ${ }^{6}$

There are several reasons why technological literacy is important for engineering students.

1. The engineering design of most products and systems requires the integration of many fields of knowledge both within and without engineering. An appreciation of knowing what you don't know and when to bring in other experts is not a genetically determined trait. It needs to be taught. Technology literacy that includes the study of such integration in a variety of modern technologies is therefore an important building block in design education.

2. Students enter engineering programs with very varied knowledge of, and experience with, technology, but almost none have a broadly informed grasp of modern technology. Thus there is little connection between what they are studying and the world of technology in which they will work. Their coursework will not do a lot to change this, except in design. From the standpoint of recruitment and retention of engineering students, this neglect is not helpful. And it may hurt efforts to reach new populations such as women and minorities. Technology literacy should help the students build their identity as an engineer with peers, family, friends, and potential employers. As such it may improve both recruitment and retention, and it may help students choose their engineering majors.

\section{Teaching TL in Engineering}

In an introduction to design class we teach problem development, customer needs, objectives trees, function decomposition design $4 \mathrm{X}$, sketching, idea generation, concept selection design embodiment, prototyping, and CAD. But we do not usually teach about technology. The students are supposed to come up with design solutions for real problems from industry, when most have with little idea about how anything works, about trends in technologies, or the tradeoffs of technologies. This may be most true of new populations entering engineering such as women and minorities. [Ironically, it is sometimes argued that the students most experienced in technology, and most likely to win design competitions in $\mathrm{K}-=12$, are often selected out in favor of those who excel in math and science.]

In an introduction to design class, each student must present a PowerPoint presentation of 8 slides in 8 minutes on a technology that they choose. They must explain how it works, what its value or market share is, the tradeoffs, the competition, and the trends. And they must provide references. For example, in a class of 32 students the students hear about 30 different technologies, because repetition is infrequent. The students may still be ignorant of most technologies, but they are far better off than they were. And it can involve enlightening their professors about some of the technologies chosen. The following assignment has been used for the last four semesters. 


\section{The Assignment}

\section{Technology Presentation}

1. The objective of this is to raise your awareness of technology and help close the gaps in the analysis - design - technology trichotomy. It will help you sound like an engineer with peers, family, friends, and potential employers. It should also develop your ability in an important design skill, weighing tradeoffs. The presentations will be given individually throughout the semester, thus students learn about 30 technologies. A few may do the same subject, but this will be monitored.

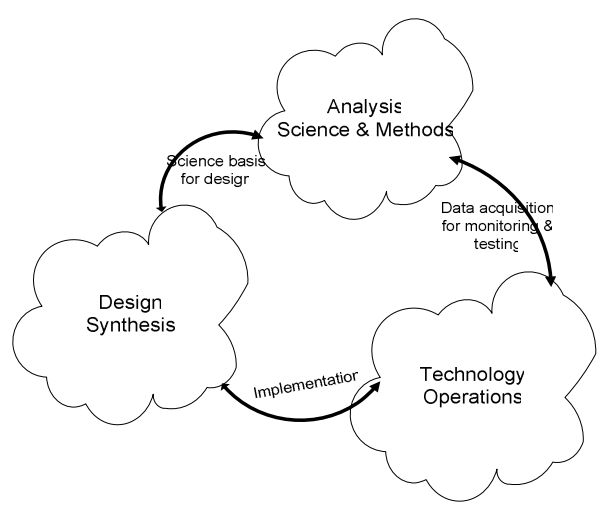

2. The assignment is to select any technology and describe in 8 slides or less and 8 minutes or less. The title slide is not counted.

a. How it works

b. For whom it works

c. Its deployment: market value or other measure of value

d. Its competition

e. The trends

f. The tradeoffs: strongest and weakest features (what the critics say)

g. List references

3. The topic may be on technologies such as high intensity white LED lights, or microbial disposal of toxic waste, or on a major project (system), such as the Three Gorges or (saving) Venice. It could also focus on a failure like the Columbia Shuttle, or the New Orleans levees. See helpful links below.

4. Note: Some generic technology families like explosives, or nanotechnology, may appear to have no competition. They do.

\section{Comments on the Assignment}

The assignment requires a lot of class time. We need to find about 30 minutes for 3 presentations for each of 10 weeks of the 15 week semester. Our introduction to design class meets for 6 hours each week and so it is not hard to do it. It even helps provide continuity in a 
class that covers many different subjects. However, in a standard class that only meets for three, 50-minute periods a week it is not so easy to do. Options include team presentations or take home assignments, smaller classes, and five-minute presentations. There are tradeoffs with all of the options. Teams of two students reduce the impact on class time by $50 \%$, but it also reduces the number of technologies the students hear about by the same amount. However, this is much better than take-home assignments where there is no further exposure to any technologies other than the one covered by the student.

The assignment allows students to choose their topics. There are tradeoffs with this. One could get better coverage by assigning topics, but student motivation is better when they choose. A compromise might be to designate areas of technology such as information technology, structures, infrastructure, energy, bio-technology, and transportation and let students choose within these categories while insisting that each gets covered by the class as a whole. By and large, however, these topic areas do get covered by student choices

While integrated design showing disciplinary contributions is important, it is not yet explicit in the assignment and it probably should be.

The curriculum has not yet been formally assessed, informal polls always get positive responses for this assignment and it is usually well done. A retro-active formal assessment is planned.

\section{Student Topics}

The topics chosen by students for this assignment are provided below in Table 1. The class size normally ranges from 28-34.

Table 1: Student Choices for Technology Presentations

\begin{tabular}{|l|l|l|l|}
\hline Fall 2006 & Spring 2006 & Spring 2006 & Fall 2005 \\
\hline Hybrid cars (3) & Nano battery (2) & Hybrid cars & Google earth \\
\hline $\begin{array}{l}\text { CVT } \\
\text { Transmissions }\end{array}$ & $\begin{array}{l}\text { Optical character } \\
\text { recognition }\end{array}$ & Flywheels & $\begin{array}{l}\text { SCBA alternative } \\
\text { to SCUBA }\end{array}$ \\
\hline Hydrogen cars & Nintendo & Biodiesel & Fuel cells \\
\hline $\begin{array}{l}\text { Trans-Atlantic } \\
\text { Tunnel }\end{array}$ & $\begin{array}{l}\text { Alternative fuel } \\
\text { vehicles }\end{array}$ & $\begin{array}{l}\text { Integrated } \\
\text { Gasification cycles }\end{array}$ & $\begin{array}{l}\text { Oakley hi } \text { - def } \\
\text { HD sun glasses }\end{array}$ \\
\hline Freedom ship & Memory metal & nanotechnology & Cell phones \\
\hline $\begin{array}{l}\text { Hydro-electric } \\
\text { energy }\end{array}$ & $\begin{array}{l}\text { Noise cancelling } \\
\text { headphones }\end{array}$ & Artificial Heart & $\begin{array}{l}\text { Liquid crystal on } \\
\text { silicon displays }\end{array}$ \\
\hline Dig. Audio Players & Holograph DVD & LEDs & Night vision \\
\hline Wind Power & DLP & High speed rail & Fiber optics \\
\hline Wi-Fi & Liquid metal & Segways & Radar \\
\hline UAVs & Intel chip in mac & Bluetooth & Microwave ovens2 \\
\hline Play Station 2 & Green building & Cell phones & explosives \\
\hline Organic LEDs & Minivans & MP3 players & iPOD \\
\hline GENx turbofan & Vacuum tube amp & Blu-Ray & nanotechnology \\
\hline Plasma TV (2) & Smart phones & Pebble bed reactor & bluetooth \\
\hline Networked cars & Nuclear power & LCDs & CDs \\
\hline VOIP & Etch-a-Sketch & Electric cars & Radio Astronomy \\
\hline Moeller Sky Car & Blu-Ray & Plasma displays & Webservers \\
\hline
\end{tabular}




\begin{tabular}{|l|l|l|l|}
\hline Gibbs Aquada Car & Tivo & iPODs & Precision agric. \\
\hline GPS & Titanium & Kegbot & Vacuum tube amp \\
\hline $\begin{array}{l}\text { F 35 Joint Strike } \\
\text { Fighter }\end{array}$ & $\begin{array}{l}\text { Direct shift } \\
\text { gearbox }\end{array}$ & $\begin{array}{l}\text { Wearable health } \\
\text { monitors }\end{array}$ & $\begin{array}{l}\text { RTG Radio Isot. } \\
\text { Thermal Generator }\end{array}$ \\
\hline Sil. chip lasers & Smoke detectors & Evo. Power reactor & Super cavitation \\
\hline VTOL Aircraft & LCDs & Solar energy & DLP TV \\
\hline Fiber optic cables & XBox 360 & Exubera & Ion thruster \\
\hline Falkirk wheel & Maglev trains & Space Ship One & Digital camera \\
\hline LCDs & Smart bridge tech. & Rotary Engine & Radiant heating \\
\hline Blu-Ray & Insulin pumps & Skycars (2) & MRI \\
\hline & $\begin{array}{l}\text { Rebreathers } \\
\text { (SCUBA) }\end{array}$ & $\begin{array}{l}\text { Human animal } \\
\text { hybrids }\end{array}$ & \\
\hline & Blink cards & Blink technology & \\
\hline & $\begin{array}{l}\text { Forward facing } \\
\text { propellers in boats }\end{array}$ & Reverse osmosis & \\
\hline & Jaws of life & Sports Video Cam & \\
\hline & & Compressors & \\
\hline & & Fuel cell & \\
\hline & & DNA computers & \\
\hline
\end{tabular}

Most notable about these lists of topics are the lack of repetition even from class to class and semester to semester. It is a comment on the complexity and pervasiveness of modern technology. The same assignment in an honors section yielded much the same results in terms of topics chosen and the lack of repetition.

\section{Conclusion}

The next step is a formal assessment linked to specific learning objectives. Informally, it seems to be popular and a way of providing a sense of continuity and student involvement in the course.

\section{References}

1. Steen, Lynn Arthur "The New Liberal Arts Program, Alfred P. Sloan Foundation, 19801992." College Board 1999. Emphasis on Quantitative Literacy.

http://www.stolaf.edu/other/ql/nla.html Viewed 1/15/2007

2. http://www.nae.edu/nae/techlithome.nsf/ The home site for technological literacy of the National Academy of Engineering. Viewed 1/15/2007.

3. Krupczak, John Jr. and David F. Ollis. Improving the Technological Literacy of Undergraduates: Identifying the Research Issues, Report from a workshop sponsored by the National Science Foundation and held at the National Academy of Engineering, April 2005. P 149.

4. Devon, Richard F., "In Praise of Computer Illiteracy," Bulletin of Science, Technology, and Society," Vol. 7, Nos. 5 \& 6, 1987.

5. http://en.wikipedia.org/wiki/Digital_divide Viewed 1/15/2007

6. Billington, David P. The Tower and the Bridge: The New Art of Structural Engineering. Princeton University Press, 1985. 